\title{
Anti-Yo antibody-mediated paraneoplastic cerebellar degeneration associated with cognitive affective syndrome in a patient with breast cancer: a case report and literature review
}

\author{
M. Le May MD MSc* and S. Dent MD ${ }^{\dagger}$
}

\begin{abstract}
Breast cancer is the most common cancer in women, with $15 \%-25 \%$ of those tumours overexpressing the human epidermal growth factor receptor 2 (HER2), which is associated with more aggressive disease. On rare occasions, patients present with a paraneoplastic syndrome months to years before their cancer diagnosis. Paraneoplastic cerebellar degeneration (PCD) is associated with fewer than $1 \%$ of cancers and is strongly associated with breast and gynecologic malignancies. Anti-Yo antibody is the antibody most frequently identified with the syndrome, and it is associated with a very poor prognosis. Recent studies have implicated a relationship between overexpression of HER2 and anti-Yo-mediated PCD. Current PCD treatments include tumour removal, chemotherapy, targeted therapy, and immune-suppressive treatments. Outcomes of PCD are typically poor, and no guidelines for treatment currently exist. Early recognition followed by rapid initiation of treatment remains the cornerstone of therapy.

Here, we present a case of anti-Yo-antibody PCD secondary to estrogen and progesterone receptor-negative, HER2-positive breast cancer. Despite treatment with mastectomy, chemotherapy, and HER2-targeted therapy, no significant neurologic improvement was achieved, and cerebellar cognitive affective syndrome subsequently developed.
\end{abstract}

Key Words Paraneoplastic syndrome, HER2, anti-Yo antibody, breast cancer, cerebellar degeneration, cognitive affective syndrome

\section{INTRODUCTION}

Paraneoplastic cerebellar degeneration (PCD) is a rare and severely debilitating immune-mediated disorder. It has been associated with fewer than $1 \%$ of cancers, including small-cell carcinoma of the lung, Hodgkin lymphoma, breast cancer, and gynecologic malignancies ${ }^{1}$. Anti-Yo antineuronal antibody, also called Purkinje cell cytoplasmic antibody type 1, is highly specific and the antibody most frequently identified in patients with PCD, followed by anti$\mathrm{Hu}$, anti-Tr, anti-Ri, and anti-mGluR1 ${ }^{2}$. In approximately $40 \%$ of patients, no antibodies are identified ${ }^{3}$.

Each autoantibody is associated with different tumour types. Because PCD can present months to years before the cancer is discovered ${ }^{4,5}$, the nature of the antibody guides the search for the primary cancer ${ }^{2}$. Anti-Yo-mediated PCD has a female predominance and tends to occur in women more than 60 years of age ${ }^{6}$. Among patients with anti-Yo antibodies, $75 \%$ have a pelvic gynecologic malignancy, and $10 \%-15 \%$ have breast cancer ${ }^{7-10}$.

By definition, the symptoms of PCD are seen in the absence of brain metastasis or direct central nervous system invasion and are not secondary to side effects of treatments, metabolic derangements, or infection ${ }^{11}$. It affects the vermis and midline cerebellum earlier and more severely than it does the cerebellar hemispheres ${ }^{12}$. It typically presents as acute or subacute moderate-to-severe trunk and limb ataxia, nystagmus, vertigo, dysarthria, and sometimes 
diplopia or oscillopsia ${ }^{1}$. The deficits are always bilateral, but often show some asymmetry ${ }^{2}$. Less common presentations are acute stroke-like presentations, ataxic dysarthria, or episodic vertigo that can initially mimic benign positional vertigo $^{12}$. Many affected individuals have tremor of the trunk and head, and a marked high-amplitude intention tremor that causes difficulty in everyday tasks requiring the upper limbs. Communication can be impaired not only because of severe dysarthria, but because PCD also causes prosody loss, irregular articulation, and speech rate and volume ${ }^{12}$. The ocular motor abnormalities that accompany PCD can be complex because there is always some degree of brainstem encephalitis that can disrupt either vestibulocerebellar connections or associated ocular brainstem nuclei ${ }^{12}$. The symptoms evolve quickly to affect all cerebellar functions ${ }^{12}$. Although severe vertigo and nausea can resolve, neurologic impairment reaches its peak within 6 months and then stabilizes. Many patients are left disabled, and $70 \%$ are unable to ambulate ${ }^{2}$. Once the disease stabilizes, the severe vertigo with nausea that occurs early in the disease can resolve ${ }^{12}$.

Estimates suggest that $20 \%$ of patients will develop mild memory and cognitive deficits ${ }^{4,13}$, with rare cases of PCD resulting in cerebellar cognitive affective syndrome (CAS), which is characterized by deficits in executive function, spatial cognition, visual-spatial memory, and expressive language, with disinhibited or inappropriate behavior $^{8,13,14}$. Cognitive affective syndrome is typically seen secondary to stroke, multiple sclerosis, amyotrophic lateral sclerosis, traumatic brain injury, or paraneoplastic disorders ${ }^{15-17}$. Anti-Yo is known to cause paraneoplastic sensory peripheral neuropathy and opsoclonus-myoclonus syndrome $^{1}$. To our knowledge, anti-Yo related cas has not previously been reported.

Efforts are currently under way to elucidate the exact mechanism of this potent immune response. Investigations of patients with breast cancer have shown that a correlation of anti-Yo-positive PCD with human epidermal growth factor receptor 2 (HER2) overexpression in breast cancers might exist, given that trastuzumab therapy added to paclitaxel produced improvement in cerebellar symptoms in select patients ${ }^{18,19}$. Here, we present a case of anti-Yo-associated PCD in a patient with estrogen and progesterone receptor-negative, HER2-positive breast cancer who developed associated cas.

\section{CASE DESCRIPTION}

A previously healthy 53-year-old postmenopausal woman presented to our emergency department with symptoms of subacute dizziness and ataxia, blurred vision, and intermittent horizontal diplopia inconsistent with direction of gaze. Computed tomography (Ст) of head, without contrast, was normal, and she was sent home with a referral for physiotherapy.

The woman returned to the emergency department a second time 4 months later because of ongoing symptoms. In addition, she had recently noticed a new lump in her left breast. Imaging of head by ст and ст angiography was performed and reported as normal. Epley maneuver for suspected benign paroxysmal positional vertigo was attempted by the emergency physician without success, and the patient was discharged with follow-up at the women's breast health centre clinic.

The woman was seen urgently at the women's breast health centre clinic, where ultrasound-guided biopsy revealed high-grade invasive ductal carcinoma of the breast. She underwent a left-breast simple mastectomy with left axillary sentinel lymph node biopsy. Of 3 nodes, 1 was positive for metastatic carcinoma, with a $0.4 \mathrm{~cm}$ deposit. Imaging by ст of chest, abdomen, and pelvis and a bone scan were all negative for metastatic disease. Her final pathology report indicated a T2 $(2.6 \mathrm{~cm}), \mathrm{N} 1$ (1 of 3 nodes positive), M0, grade 3 invasive ductal carcinoma of the left breast that was estrogen and progesterone receptornegative and HER2-positive.

The patient returned to the emergency department a third time, 1 month after being seen in the breast centre clinic. She had worsening dysarthria, and writing and typing difficulties, but denied weakness or coordination problems. She had stopped driving and working; after 2 falls, she felt that she was no longer able to live at home alone. Neurology was consulted for ongoing vertigo. On neurologic examination, she was found to have dysarthria, downbeat gaze-evoked nystagmus, wide-based gait with significant unsteadiness, truncal and appendicular ataxia, and difficulty with fine motor control. Magnetic resonance imaging (MRI) of head showed no abnormalities.

The patient was admitted to hospital under Neurology with suspected paraneoplastic syndrome. She was treated with a course of intravenous immunoglobulin (IVIG) without noticeable improvement. Serum antibody panel testing was positive for anti-Yo antibodies. Her subacute presentation of severe pan-cerebellar deficits, a recent diagnosis of breast cancer, normal MRI, and positive antibodies confirmed a diagnosis of paraneoplastic cerebellar degenerative syndrome. Because the diagnosis was confirmed, cerebrospinal fluid analysis and electroencephalography were not performed. Physiotherapy was initiated for ongoing truncal ataxia and gait disturbance. She received a second trial of IVIG with no clinical improvement; hence, further immunosuppressive treatments with IVIG, plasmapheresis, or steroids were felt unlikely to be beneficial.

The medical oncology team then initiated a course of chemotherapy consisting of 4 cycles of doxorubicincyclophosphamide every 3 weeks, followed by 12 cycles of weekly paclitaxel combined with trastuzumab. The 12th cycle of paclitaxel was held because of the development of sensory neuropathy. Trastuzumab was continued at 3-week intervals for a 1-year course.

Given that micrometastasis could not be ruled out, the patient was informed of the potential for continued neurologic decline. Because cyclophosphamide chemotherapy is also immunoablative, there was hope that its use would help to curtail any residual autoimmune attack.

Although the patient's deficits stabilized after her mastectomy, no improvement in her neurologic condition was observed after the 2nd cycle of chemotherapy with doxorubicin-cyclophosphamide. She had persistent nystagmus and oscillopsia, and ongoing disabling dysarthria-specifically, difficulty pronouncing vowels and enunciating the letters B and P. She had pronounced 
truncal ataxia and a very unsteady gait with significant loss of postural reflexes. Cerebellar deficits were more pronounced on the right, but she had significant difficulty with left-sided dexterity and new-onset dysphagia. No dystonia, chorea, or myoclonus was evident. At this point, rehabilitation was suggested. Seven months after the onset of her initial symptoms, she required transfer to a nursing home. She had become wheelchair-dependent and was unable to ambulate or to provide self-care. Most of her speech is unrecognizable.

Unfortunately, this woman's cerebellar syndrome did not respond to either chemotherapy or immunotherapy with IVIG. Repeat MRI of head 9 months after symptom onset showed a new hyperintense T2 lesion of the left anterior external capsule, without signs of cerebellar atrophy. Treatment focus was shifted to symptomatic therapy, and she was admitted to the inpatient rehabilitation centre.

While in rehabilitation, the patient was observed to have labile affect, impaired selective attention, and executive dysfunction, including distractibility, ideational perseveration, trouble with initiation, performance inconsistency, poor frustration tolerance, ideational apraxia, and emotional dysregulation. There was no evidence of oculomotor or buccofacial apraxia, but she showed some ideomotor apraxia, particularly of the left hand. She also displayed left-right confusion in extra-personal space. She was noted to have significant difficulty with rapid processing of complex information. Given those deficits, she was diagnosed with cas.

With intense care over several months, she experienced moderate improvement in her ataxia, but continued to have a profound reduction in postural reflexes. Her poor functional status required that she be discharged to a longterm care facility where she currently resides.

\section{DISCUSSION}

This case is the first, to our knowledge, of anti-Yo PCD secondary to breast cancer associated with cAs. Whether HER2 status has any relationship with the cAs is unknown.

Emerging studies show that the cerebellum is implicated in higher cortical function ${ }^{20}$. Cases of paraneoplastic limbic encephalitis commonly occur in combination with PCD and have been reported to cause CAs $^{21,22}$. Our patient did not have clinical features of paraneoplastic limbic encephalitis and did not have antibodies or MRI findings to suggest a coexisting disorder. Collinson et $a l .{ }^{16}$ previously described a case of cas associated with ovarian PCD, which was also noted to occur separately from paraneoplastic limbic encephalitis. A recent report by Martin et al. ${ }^{13}$ described the first case of pseudobulbar affect associated with anti-Yo PCD secondary to breast cancer. Our patient had frontal executive functional impairment in addition to progressive cerebellar neurologic decline. The mechanism behind anti-Yo-mediated cas in PCD remains to be elucidated.

By the time atrophy can be seen on MRI, significant irreversible damage has been sustained. Atrophy tends to be worse in midline structures ${ }^{12}$, and anti-Yo antibodies can affect the function of the pyramidal tract and brainstem $^{23}$. Whether the frontal executive problems of cAs are secondary to destruction of those areas or a result of cerebellar lesions disrupting circuits from the cerebellum to the cortex is unknown.

At autopsy, PCD patients show decreased cerebellar size, diffuse loss of Purkinje cells throughout the cerebellar cortex, and also a loss of granule and basket cells ${ }^{1}$. Although Mri can be entirely normal early in the disease, pathology shows mild perivascular lymphocytic cuffing, parenchymal microglial activation, and the presence of CD8 lymphocytes in and around the Purkinje cell layer of the cerebellum ${ }^{24}$. Later cerebellar pathology can show severe or complete loss of Purkinje cells without inflammatory changes ${ }^{25,26}$.

The irreversible neuronal damage caused by the $\mathrm{T}$ cell attack in these patients explains their poor response to treatment and implies a poor prospect for recovery. Further mechanistic studies are needed to determine the exact role of anti-Yo antibody and T cell-mediated neuronal destruction. Post-mortem analysis has been fundamental in understanding the underlying pathology given that animal studies are currently lacking. Once the mechanism of cellular injury can be further elucidated, targeted therapeutic strategies can be developed and optimized.

In most patients, symptoms of PCD present months to years before a diagnosis of cancer is made ${ }^{1,2}$ and can develop at any stage of cancer with no relationship to nodal status $^{27,28}$. It should be suspected when the patient develops severe cerebellar signs and symptoms in less than 12 weeks with normal MRI ${ }^{10}$. A definitive diagnosis can be made by detection of the antibody in either serum or cerebrospinal fluid (CSF) ${ }^{29}$; however, up to $40 \%$ of patients test negative, and so the absence of antibodies does not rule out the syndrome. Antibody panels can take weeks to return, and so, while waiting for confirmatory results, immunosuppressive treatments should be initiated to potentially halt the destruction as early as possible. The CSF analysis is usually mildly abnormal and could show mild-to-marked lymphocytosis, increased proteins, a high immunoglobulin $\mathrm{G}$ index, and oligoclonal bands ${ }^{30}$. For antibody-negative patients, an international panel of neurologists defined 4 components that are required for the diagnosis ${ }^{31-33}$ :

presence of neurologic symptoms;

a diagnosis of cancer within 4 years from the onset of the neurologic manifestations;

exclusion of other neurologic disorders; and

at least one of

- CSF analysis showing inflammation with negative cytology,

- MRI of brain demonstrating a lesion in the temporal lobe, or

- the finding of epileptic activity in the temporal lobes by electroencephalogram.

Appropriate initial and repeat screening should be implemented to reveal the underlying instigating cancer. If screens are all negative, repeat screening should be performed in 3-4 months, followed by regular screening every 6 months for 4 years $^{34,35}$.

Paraneoplastic cerebellar degeneration is severely debilitating and can represent a challenge to diagnose. 
It is under-recognized, and because of the rarity of the syndromes, no randomized controlled trials have been conducted to develop best treatment strategies, and no evidence-based guidelines for effective treatment are available ${ }^{2,36}$. Current treatment options are limited to IVIG, corticosteroids, plasmapheresis, rituximab, and cyclophosphamide, with little success and only isolated reports of improvement ${ }^{29}$. The current cornerstone of treatment involves removal of the underlying antigen through aggressive treatment of the malignancy, followed by physiotherapy and symptomatic management of neurologic sequelae ${ }^{2,13,37}$.

Oncologic remission can halt further progression, with neurologic symptoms improving in approximately $10 \%$ of patients ${ }^{18,38}$. Late improvement in symptoms is rare, given the early diffuse neuronal loss ${ }^{10}$. Several case studies have shown that, for many patients, the best response achieved with treatment is stable disease, and those treated more than 3 months after onset experience the poorest outcomes ${ }^{39}$. There is no guarantee, however, that tumour treatment will halt progression; in some patients, progression has continued even with reduced antibody titers, highlighting the current lack of effective treatment ${ }^{40}$. A recent small retrospective study found that, despite the poor neurologic prognosis, intense inpatient rehabilitation helped patients to experience statistically significant functional improvement. That improvement was suspected to be compensatory in nature rather than true neurologic recovery ${ }^{41}$.

Although oncologic outcomes are better for patients with paraneoplastic syndrome than for patients without the syndrome ${ }^{5}$, PCD associated with anti-Yo antibody (compared with other paraneoplastic antibodies) has a poorer prognosis, leading to severe neurologic impairment, immobility, and a significantly shorter overall survival ${ }^{2}$. Most patients become confined to bed within 3 months of diagnosis ${ }^{6}$, with a median survival of 100 months after diagnosis of breast cancer-related PCD and of 22 months after diagnosis of gynecologic cancer-related $\mathrm{PCD}^{42}$.

Overexpression of HER2 is associated with aggressive tumour behavior, early invasion of regional lymph nodes, and a poorer prognosis even in the absence of a concomitant PCD disorder ${ }^{43}$. Case reports of HER2-directed treatment in breast cancer-related PCD have yielded conflicting results. In a case described by Sancho et al. ${ }^{18}$, a patient was treated with trastuzumab, IVIG, prednisone, and cytostatic agents. After 3 months, no anti-Yo antibody was observable in either serum or CSF, and the patient experienced stabilization, with improvement in her clinical condition. However, in a comparable patient, neurologic deterioration continued despite receipt of similar treatments alongside chemotherapy and trastuzumab ${ }^{19}$.

In a retrospective study by Rojas-Marcos et $a l .{ }^{44}$, the authors concluded that overexpression of HER2 seems to be an important requirement to develop an anti-Yoassociated PCD. In an analysis of 27 patients, they found that HER2 was overexpressed in $96.3 \%$ of patients with anti-Yo-associated PCD, but in only $10.5 \%$ of patients with paraneoplastic neurologic syndromes associated with Ri antibodies. Regardless of the treatments received, none of the patients in the study experienced improvement in their clinical condition. Similarly, a review of previously published cases of breast cancer (Table I) shows that, regardless of treatment, outcomes are poor. Interestingly, no correlation between HER2-positive breast cancers with high CDR2 onconeural antigen expression was seen, and the mechanism behind increased anti-Yo PCD and HER2 overexpression remains unclear. There is a potential that these more aggressive tumours not only spread earlier to lymph nodes where antigens can be presented to the immune system to initiate a response, but that the presence of undetected micrometastasis continues to provoke a potent immune response (Table I).

Our patient received chemotherapy, IVIG, and trastuzumab, and yet, despite the combined efforts of oncologic treatment, immunosuppressive therapies, and rehabilitation, became wheelchair-dependent, with multiple cognitive disabilities. Clearly, a better understanding of the underlying mechanism to clarify the means of immune destruction and to determine how antibody and $\mathrm{T}$ cells work together to produce Purkinje cell death is required to develop more effective treatments. Furthermore, anti-Yo involvement in the impairment of higher cortical function remains unclear.

\section{SUMMARY}

We present a case of CAS associated with anti-Yo PCD in a patient with stage II estrogen and progesterone receptornegative, HER2-positive breast cancer. Our report describes the profoundly debilitating course of this disease and the difficulties faced in establishing the diagnosis. It highlights the need for increased awareness of this condition, with the hope of initiating therapy at an earlier stage to limit the severe and irreversible complications associated with the disease. A high degree of suspicion is required given the rarity of the condition, normal routine laboratory results, and normal initial imaging. Finally, our case highlights the paucity of satisfactory treatments and the need for research that will add novel and more effective therapies to manage this devastating disease, which so profoundly affects quality of life for those who develop it.

\section{CONFLICT OF INTEREST DISCLOSURES}

We have read and understood Current Oncology's policy on disclosing conflicts of interest, and we declare that we have none.

\section{AUTHOR AFFILIATIONS}

*Department of Medicine, University of Ottawa, and ${ }^{\dagger}$ Department of Medicine, Division of Medical Oncology, University of Ottawa, Ottawa, ON.

\section{REFERENCES}

1. Fanous I, Dillon P. Paraneoplastic neurological complications of breast cancer. Exp Hematol Oncol 2015;5:29.

2. Shams'ili S, Grefkens J, de Leeuw B, et al. Paraneoplastic cerebellar degeneration associated with antineuronal antibodies: analysis of 50 patients. Brain 2003;126:1409-18.

3. Mason WP, Graus F, Lang B, et al. Small-cell lung cancer, paraneoplastic cerebellar degeneration and the Lambert-Eaton myasthenic syndrome. Brain 1997;120:1279-300.

4. Peterson K, Rosenblum MK, Kotanides H, Posner JB. Paraneoplastic cerebellar degeneration. I. A clinical analysis of 55 anti-Yo antibody-positive patients. Neurology 1992;42:1931-7. 
TABLE I Details of diagnosis, treatment, and clinical outcomes in previous case reports of anti-Yo-mediated paraneoplastic cerebellar degeneration (PCD) in patients with breast cancer

\begin{tabular}{|c|c|c|c|c|}
\hline Reference & $\begin{array}{l}\text { Details of } \\
\text { the diagnosis }\end{array}$ & Immunotherapy & Other therapy ${ }^{a}$ & $\begin{array}{l}\text { Clinical outcome } \\
\text { of PCD }\end{array}$ \\
\hline O'Brian et al., $1995^{45}$ & $\begin{array}{l}\text { Grade } 3 \\
\text { adenocarcinoma }\end{array}$ & $\begin{array}{c}\text { Plasma exchange (10 courses) } \\
\text { given over } 2 \text { weeks }\end{array}$ & $\begin{array}{l}\text { Doxorubicin-cyclophosphamide } \\
\text { (3 doses) in a 3-weekly cycle }\end{array}$ & $\begin{array}{l}\text { Progressively } \\
\text { declined } \\
\text { until death }\end{array}$ \\
\hline Dorn et al., $2003^{37}$ & $\begin{array}{l}\text { ER- and PgR-negative, } \\
\text { HER2-positive }\end{array}$ & None & $\begin{array}{l}\text { Epirubicin-cyclophosphamide } \\
\text { (4 cycles) and focal radiation }\end{array}$ & $\begin{array}{c}\text { Stable; } \\
\text { no improvement }\end{array}$ \\
\hline Rubello et al., $2005^{46}$ & $\begin{array}{c}\text { Infiltrating } \\
\text { ductal carcinoma }\end{array}$ & None & Not available & Not available \\
\hline Mathew et al., $2006^{47}$ & $\begin{array}{l}\text { ER- and PgR-negative, } \\
\text { HER2-positive }\end{array}$ & Oral prednisone & Chemotherapy and focal radiation & $\begin{array}{c}\text { Stable; } \\
\text { no improvement }\end{array}$ \\
\hline Sancho et al., $2006^{18}$ & $\begin{array}{l}\text { Grade } 3 \text { infiltrating } \\
\text { ductal carcinoma, } \\
\text { ER- and PgR-positive, } \\
\text { HER2-positive }\end{array}$ & $\begin{array}{l}\text { Intravenous immunoglobulin } \\
\text { and prednisone }\end{array}$ & $\begin{array}{l}\text { Paclitaxel-trastuzumab (12 cycles) } \\
\text { followed by } 1 \text { year of trastuzumab; } \\
\text { later started on anastrozole }\end{array}$ & $\begin{array}{l}\text { Partial clinical } \\
\text { improvement }\end{array}$ \\
\hline Dalmau et al., $2007^{14}$ & $\begin{array}{l}\text { ER- and PgR-negative, } \\
\text { HER2-positive }\end{array}$ & $\begin{array}{l}\text { High-dose methylprednisolone } \\
\text { followed by prednisone taper }\end{array}$ & $\begin{array}{l}\text { Vinorelbine-trastuzumab for } 6 \\
\text { months }\end{array}$ & $\begin{array}{c}\text { Stable; } \\
\text { no improvement }\end{array}$ \\
\hline $\begin{array}{l}\text { Rupasinghe and Butler, } \\
2007^{48}\end{array}$ & $\begin{array}{l}\text { Grade } 3 \\
\text { adenocarcinoma, } \\
\text { HER2-positive }\end{array}$ & $\begin{array}{l}\text { Intravenous immunoglobulin } \\
\text { and methylprednisolone }\end{array}$ & $\begin{array}{l}\text { No chemotherapy because of } \\
\text { poor performance status; } \\
\text { patient refused trastuzumab }\end{array}$ & $\begin{array}{l}\text { Stable; } \\
\text { minimally } \\
\text { improved }\end{array}$ \\
\hline Ogita et al., $2008^{19}$ & $\begin{array}{c}\text { Grade } 3 \\
\text { adenocarcinoma, } \\
\text { ER- and PgR-negative, } \\
\text { HER2-positive }\end{array}$ & $\begin{array}{l}\text { Intravenous immunoglobulin } \\
\text { and high-dose corticosteroids }\end{array}$ & $\begin{array}{c}\text { Doxorubicin-cyclophosphamide } \\
\text { ( } 1 \text { cycle), then } \\
\text { paclitaxel-carboplatin-trastuzumab } \\
\text { ( } 2 \text { cycles })\end{array}$ & $\begin{array}{c}\text { Transient } \\
\text { improvement, } \\
\text { then deterioration }\end{array}$ \\
\hline Plantone et al., $2011^{49}$ & Grade 2 DCIS & Several months of steroids & None & Not available \\
\hline Real et al., $2012^{50}$ & Grade 3 DCIS & $\begin{array}{l}\text { High-dose methylprednisolone } \\
\text { followed by oral prednisolone } \\
\text { and a pulse of } \\
\text { intravenous immunoglobulin }\end{array}$ & $\begin{array}{l}\text { Cyclophosphamide ( } 6 \text { months) } \\
\text { every } 3 \text { weeks }\end{array}$ & $\begin{array}{c}\text { Stable; } \\
\text { no improvement }\end{array}$ \\
\hline Key and Root, $2013^{29}$ & $\begin{array}{c}\text { Invasive } \\
\text { ductal carcinoma, } \\
\text { ER- and PgR-negative, } \\
\text { HER2-positive }\end{array}$ & $\begin{array}{l}\text { Intravenous immunoglobulin, } \\
\text { then riluzole for } 6 \text { months }\end{array}$ & $\begin{array}{l}\text { Epirubicin-cyclophosphamide-- } \\
\text { paclitaxel and trastuzumab } \\
\text { and dexamethasone }\end{array}$ & $\begin{array}{c}\text { Stable; } \\
\text { no improvement }\end{array}$ \\
\hline Poudel and Achar, $2013^{51}$ & $\begin{array}{c}\text { Grade } 2 \\
\text { ductal carcinoma, } \\
\text { ER- and PgR-negative, } \\
\text { HER2-negative }\end{array}$ & $\begin{array}{c}\text { Plasma exchange } \\
\text { (5 courses) and } \\
\text { intravenous immunoglobulin }\end{array}$ & $\begin{array}{l}\text { Not fit for adjuvant } \\
\text { chemoradiation }\end{array}$ & $\begin{array}{l}\text { Mild improvement } \\
\text { with rehabilitation }\end{array}$ \\
\hline Adama et al., $2015^{52}$ & $\begin{array}{l}\text { Grade } 3 \text { infiltrating } \\
\text { intraductal carcinoma, } \\
\text { ER- and PgR-positive }\end{array}$ & None & $\begin{array}{l}\text { 5-Fluorouracil-epirubicin- } \\
\text { cyclophosphamide (6 cycles) plus } \\
\text { radiation and tamoxifen for } 5 \text { years }\end{array}$ & $\begin{array}{l}\text { Moderate } \\
\text { improvement }\end{array}$ \\
\hline Ng et al., $2015^{53}$ & $\begin{array}{l}\text { Grade } 3 \text { invasive } \\
\text { ductal carcinoma } \\
\text { ER- and PgR-negative, } \\
\text { HER2-negative }\end{array}$ & None & Adjuvant chemotherapy & $\begin{array}{c}\text { Regained } \\
\text { functional } \\
\text { independence } \\
\text { with resolution of } \\
\text { physical impair- } \\
\text { ment }\end{array}$ \\
\hline Thapa and Basu, $2016^{54}$ & Grade 3 DCIS & None & Not available & Not available \\
\hline Kato et al., $2017^{55}$ & $\begin{array}{c}\text { Microinvasive } \\
\text { ductal carcinoma }\end{array}$ & $\begin{array}{l}\text { Intravenous immunoglobulin, } \\
\text { steroid pulse therapy } \\
\text { ( } 2 \text { courses), } \\
\text { and plasma exchange }\end{array}$ & None & Mild improvement \\
\hline Martin et al., $2017^{13}$ & $\begin{array}{l}\text { Grade } 2 \text { infiltrating } \\
\text { ductal carcinoma, } \\
\text { ER- and PgR-negative, } \\
\text { HER2-positive }\end{array}$ & $\begin{array}{l}\text { Intravenous immunoglobulin } \\
\text { monthly }\end{array}$ & $\begin{array}{c}\text { Docetaxel-carboplatin, } \\
\text { trastuzumab, and pertuzumab, } \\
\text { plus chest and axillary radiation } \\
\text { and adjuvant trastuzumab } \\
\text { and pertuzumab }\end{array}$ & $\begin{array}{c}\text { Stable; } \\
\text { brief periods of } \\
\text { symptomatic } \\
\text { improvement } \\
\text { after intravenous } \\
\text { immunoglobulin } \\
\text { treatments }\end{array}$ \\
\hline $\begin{array}{l}\text { Enríquez-Marulanda et al., } \\
2018^{56}\end{array}$ & $\begin{array}{c}\text { Infiltrating } \\
\text { ductal carcinoma, } \\
\text { ER- and PgR-negative, } \\
\text { HER2-positive }\end{array}$ & Methylprednisolone & $\begin{array}{l}\text { 5-Fluorouracil-doxorubicin- } \\
\text { cyclophosphamide-paclitaxel, } \\
\text { and trastuzumab }\end{array}$ & $\begin{array}{c}\text { Stable; } \\
\text { no improvement }\end{array}$ \\
\hline
\end{tabular}

a When available in the original case reports.

$\mathrm{ER}=$ estrogen receptor; $\mathrm{PgR}$ = progesterone receptor; DCIS = ductal carcinoma in situ. 
5. Hammack JE, Kimmel DW, O'Neill BP, Lennon VA. Paraneoplastic cerebellar degeneration: a clinical comparison of patients with and without Purkinje cell cytoplasmic antibodies. Mayo Clin Proc 1990;65:1423-31.

6. Hasadsri L, Lee J, Wang BH, Yekkirala L, Wang M. Anti-Yo associated paraneoplastic cerebellar degeneration in a man with large cell cancer of the lung. Case Rep Neurol Med 2013;2013:725936.

7. Rojas-Marcos I, Rousseau A, Keime-Guibert F, et al. Spectrum of paraneoplastic neurologic disorders in women with breast and gynecologic cancer. Medicine (Baltimore) 2003;82:216-23.

8. Posner JB. Paraneoplastic syndromes. In: DeAngelis LM, Posner JB, eds. Neurologic Complications of Cancer. Philadelphia, PA: Oxford University Press; 1995: 353-85.

9. Pittock SJ, Kryzer TJ, Lennon VA. Paraneoplastic antibodies coexist and predict cancer, not neurological syndrome. Ann Neurol 2004;56:715-19.

10. Kumari VA, Gupta P, Srivastava MV, Kumar L, Kriplani A, Bhatla N. Paraneoplastic cerebellar degeneration as the first evidence of malignancy: a case report. J Obstet Gynaecol Res 2014;40:1463-5.

11. Giometto B, Grisold W, Vitaliani R, Graus F, Honnorat J, Bertolini G on behalf of the PNS Euronetwork. Paraneoplastic neurologic syndrome in the PNs Euronetwork database: a European study from 20 centers. Arch Neurol 2010;67:330-5.

12. Vernino S. Paraneoplastic cerebellar degeneration. Handb Clin Neurol 2012;103:215-23.

13. Martin AN, Dillon PM, Jones DE, Brenin DR, Lapides DA. Anti-Yo mediated paraneoplastic cerebellar degeneration associated with pseudobulbar affect in a patient with breast cancer. Case Rep Oncol Med 2017;2017:8120689.

14. Dalmau J, Gonzalez RG, Lerwill MF. Case records of the Massachusetts General Hospital. Case 4-2007. A 56-year-old woman with rapidly progressive vertigo and ataxia. $N$ Engl Med 2007;356:612-20.

15. Tiryaki E, Horak HA. ALs and other motor neuron diseases. Continuum (Minneap Minn) 2014;20:1185-207.

16. Collinson SL, Anthonisz B, Courtenay D, Winter C. Frontal executive impairment associated with paraneoplastic cerebellar degeneration: a case study. Neurocase 2006;12:350-4.

17. Ahmed A, Simmons Z. Pseudobulbar affect: prevalence and management. Ther Clin Risk Manag 2013;9:483-9.

18. Sancho MI, Lopez MR, Martinez LC, et al. Subacute cerebellar degeneration as paraneoplastic syndrome: initial symptom of breast cancer with HER2 overexpression. Clin Breast Cancer 2006;7:79-80.

19. Ogita S, Llaguna OH, Feldman SM, Blum R. Paraneoplastic cerebellar degeneration with anti-Yo antibody in a patient with HER2/neu overexpressing breast cancer: a case report with a current literature review. Breast J 2008;14:382-4.

20. Desmond JE. Cerebellar involvement in cognitive function: evidence from neuroimaging. Int Rev Psych 2001;13:283-94.

21. Bak TH, Antoun N, Balan KK, Hodges JR. Memory lost, memory regained: neuropsychological findings and neuroimaging in two cases of paraneoplastic limbic encephalitis with radically different outcomes. J Neurol Neurosurg Psychiatry 2001;71:40-7.

22. Benke T, Wagner M, Pallua AK, Muigg A, Stockhammer G. Long-term cognitive and MRI findings in a patient with paraneoplastic limbic encephalitis. J Neurooncol 2004;66:217-24.

23. McKeon A, Tracy JA, Pittock SJ, Parisi JE, Klein CJ, Lennon VA. Purkinje cell cytoplasmic autoantibody type 1 accompaniments: the cerebellum and beyond. Arch Neurol 2011;68:1282-9.

24. Giometto B, Marchiori GC, Nicolao P, et al. Sub-acute cerebellar degeneration with anti-Yo autoantibodies: immunohistochemical analysis of the immune reaction in the central nervous system. Neuropathol Appl Neurobiol 1997;23:468-74.

25. Brain W, Daniel P, Greenfield J. Subacute cortical cerebellar degeneration and its relation to carcinoma. JNeurol Neurosurg Psychiatry 1951;14:59-75.

26. BrockS, EllisonD, FrankelJ, Davis C, Illidge T. Anti-Yo antibodypositive cerebellar degeneration associated with endometrial carcinoma: case report and review of the literature. Clin Oncol (R Coll Radiol) 2001;13:476-9.

27. Patanaphan V, Salazar OM, Risco R. Breast cancer: metastatic patterns and their prognosis. South Med J 1988;81:1109-12.

28. Hunter SF, Parisi JE, Mastovich SL, et al. Chronic progressive paraneoplasticsyndromewith prominentbrainstemandspinal cord involvement, associated with type-2 anti-neuronal nuclear antibodies (ANNA-2) and breast carcinoma [abstract 212]. J Neuropathol Exp Neurol 1995;54:464.

29. Key RG, Root JC. Anti-Yo mediated paraneoplastic cerebellar degeneration in the context of breast cancer: a case report and literature review. Psychooncology 2013;22:2152-5.

30. Mitoma H, Adhikari K, Aeschlimann D, et al. Consensus paper: neuroimmune mechanisms of cerebellar ataxias. Cerebellum 2016;15:213-32.

31. Graus F, Delattre JY, Antoine JC, et al. Recommended diagnostic criteria for paraneoplastic neurological syndromes. $J$ Neurol Neurosurg Psychiatry 2004;75:1135-40.

32. Gultekin SH, Rosenfeld MR, Voltz R, Eichen J, Posner JB, Dalmau J. Paraneoplastic limbic encephalitis: neurological symptoms, immunological findings and tumour association in 50 patients. Brain 2000;123:1481-94.

33. Said S, Cooper CJ, Reyna E, Alkhateeb H, Diaz J, Nahleh Z. Paraneoplastic limbic encephalitis, an uncommon presentation of a common cancer: case report and discussion. Am J Case Rep 2013;14:391-4.

34. Vedeler CA, Antoine JC, Giometto B, et al. on behalf of the Paraneoplastic Neurological Syndrome Euronetwork. Management of paraneoplastic neurological syndromes: report of an EFNs Task Force. Eur J Neurol 2006;13:682-90.

35. Titulaer MJ, Wirtz PW, Willems LN, van Kralingen KW, Smitt PA, Verschuuren JJ. Screening for small-cell lung cancer: a follow-up study of patients with Lambert-Eaton myasthenic syndrome. J Clin Oncol 2008;26:4276-81.

36. Greenlee JE. Treatment of paraneoplastic neurologic disorders. Curr Treat Options Neurol 2010;12:212-30.

37. Dorn C, Knobloch C, Kupka M, Morakkabati-Spitz N, Schmolling J. Paraneoplastic neurological syndrome: patient with anti-Yo antibody and breast cancer: a case report. Arch Gynecol Obstet 2003;269:62-5.

38. Candler PM, Hart PE, Barnett M, Weil R, Rees JH. A follow up study of patients with paraneoplastic neurological disease in the United Kingdom. J Neurol Neurosurg Psychiatry 2004;75:1411-15.

39. Widdess-Walsh P, Tavee JO, Schuele S, Stevens GH. Response to intravenous immunoglobulin in anti-Yo associated paraneoplastic cerebellar degeneration: case report and review of the literature. J Neurooncol 2003;63:187-90.

40. Tanaka K, Tanaka M, Igarashi S, et al. Long term course of change in anti-Yo antibody content in paraneoplastic cerebellar degeneration. J Neurol Neurosurg Psychiatry 1995;58:256-7.

41. Fu JB, Raj VS, Asher A, et al. Inpatient rehabilitation performance of patients with paraneoplastic cerebellar degeneration. Arch Phys Med Rehabil 2014;95:2496-9.

42. Rojas I, Graus F, Keime-Guibert F, et al. Long-term clinical outcome of paraneoplastic cerebellar degeneration and anti-Yo antibodies. Neurology 2000;55:713-15.

43. Piccart M, Lohrisch C, Di LA, Larsimont D. The predictive value of HER2 in breast cancer. Oncology 2001;61(suppl 2):73-82. 
44. Rojas-Marcos I, Picard G, Chinchon D, et al. Human epidermal growth factor receptor 2 overexpression in breast cancer of patients with anti-Yo-associated paraneoplastic cerebellar degeneration. Neuro Oncol 2012;14:506-10.

45. O’Brien TJ, Pasaliaris B, D’Apice A, Byrne E. Anti-Yo positive paraneoplastic cerebellar degeneration: a report of three cases and review of the literature. JClin Neurosci 1995;2:316-20.

46. Rubello D, Vitaliani R, Rigoni MT, et al. A rare case of paraneoplastic cerebellar degeneration discovered by whole-body F-18 FDG PET. Clin Nucl Med 2005;30:704-6.

47. Mathew RM, Cohen AB, Galetta SL, Alavi A, Dalmau J. Paraneoplastic cerebellar degeneration: Yo-expressing tumor revealed after a 5-year follow-up with FDG-PET.JNeurol Sci2006;250:153-5.

48. Rupasinghe J, Butler E. Progressive ataxic gait disorder. JClin Neurosci 2007;14:153-7.

49. Plantone D, Caliandro P, Iorio R, et al. Brainstem and spinal cord involvement in a paraneoplastic syndrome associated with anti-Yo antibody and breast cancer. J Neurol 2011;258:921-2.

50. Real R, Oliveira A, Nadais G, Loureiro J, Garrett MC. The role of breast MRI in the investigation of anti-Yo positive paraneoplastic cerebellar degeneration. BMJ Case Rep 2012;2012:pii:bcr1120115225.
51. Poudel CK, Achar KN. Gross cerebellar paraneoplastic neurological disorder in a patient with an occult breast cancer. BMJ Case Rep 2013;2013:pii:bcr2012008208.

52. Adama D, Moussa B, Emmanuel M, Dennis U. Breast cancer revealed by a paraneoplastic cerebellar syndrome: about one case and literature review. Pan Afr Med J 2015;22:25.

53. Ng YR, Ho CD, Ng WL, Tan SM. Paraneoplastic cerebellar degeneration and dermatomyositis as first manifestations of underlying breast malignancy: a report of two cases and a brief review of the subject. Surg Case Rep 2015;1:59.

54. Thapa P, Basu S. Diagnosis of dual malignancy by ${ }^{18} \mathrm{~F}-\mathrm{FDG}$ PET/ Ст in the setting of paraneoplastic cerebellar degeneration. J Nucl Med Technol 2016;44:52-3.

55. Kato N, Hashida G, Konaka K. Rehabilitation for a patient with anti-Yo antibody-positive paraneoplastic cerebellar degeneration caused by breast cancer: a case report and literature review. Medicine (Baltimore) 2017;96:e8468.

56. Enríquez-Marulanda A, Beltrán-Osorio LD, Escobar LA, Granados AM, Velásquez-Lasprilla F, Orozco JL. Anti-Yoassociated paraneoplastic cerebellar degeneration manifesting as acute cerebellitis with posterior cranial fossa hypertension. World Neurosurgery 2018;112:117-22. 